\title{
IMPLIKASI HUKUM KONTRAK BISNIS INTERNASIONAL YANG DIBUAT DALAM BAHASA ASING
}

\author{
Chintya Indah Pertiwi, F.X. Joko Priyono \\ Program Studi Magister Kenotariatan, \\ Fakultas Hukum, Universitas Diponegoro
}

\begin{abstract}
Article 31 in Law no. 24 of 2009 requires the use of the Indonesian language in any agreement involving Indonesian and foreign parties in the contracts made. Judicial practice, there is a difference judge consideration related to the obligation of using the Indonesian language. The existence of these two different judgments creates legal uncertainty. The approach used in this research is normative juridical. The result of research that there is no definite understanding what is causa or cause in contract. The legal implications of contracts made in foreign languages are null and void. The existence of differences in the judgment of judges' considerations, causes legal uncertainty. Lawmakers should be more careful in formulating the Article and test its consequences. In addition, Law Number 24 Year 2009 needs to be revised, especially regarding sanctions if violated Article 31
\end{abstract}

Keywords : Legal Implication, International Commercial Contract, Foreign Language.

\begin{abstract}
Abstrak
Pasal 31 dalam Undang-Undang No. 24 Tahun 2009 mewajibkan penggunaan bahasa Indonesia dalam setiap perjanjian yang melibatkan pihak Indonesia dan pihak asing dalam kontrak yang dibuat. Praktik peradilan, terjadi perbedaan pertimbangan hakim terkait kewajiban penggunaan bahasa Indonesia. Adanya dua putusan hakim yang berbeda ini menimbulkan ketidak pastian hukum. Pendekatan yang digunakan dalam penelitian ini adalah yuridis normative. Hasil penelitian bahwa belum ada pengertian pasti apa itu causa atau sebab dalam kontrak. Implikasi hukum kontrak yang dibuat dalam bahasa asing adalah batal demi hukum Adanya perbedaan pertimbangan putusan hakim, menyebabkan adanya ketidak pastian hukum hukum.Pembuat undang-undang seharusnya lebih cermat dalam memformulasikan Pasal dan melakukan uji konsekuensi terhadapnya.Selain itu, Undang-Undang Nomor 24 Tahun 2009 perlu direvisi khususnya mengenai sanksi jika dilanggarnya Pasal 31.
\end{abstract}

Kata Kunci : Implikasi hukum, Kontrak Bisnis Internasional, Bahasa Asing

\section{A. Pendahuluan}

Sejak pengundangan Undang-Undang No. 24 Tahun 2009 tentang Bendera, Bahasa, dan Lambang Negara, serta Lagu Kebangsaan pada tanggal 9 Juli 2009 ("UU 
Bendera, Bahasa dan Lambang Negara serta Lagi Kebangsaan”), berdasarkan Pasal 31 ayat (1) menyebutkan bahwa :

"Bahasa Indonesia Wajib digunakan dalam nota kesepahaman atau perjanjian yang melibatkan Negara, Instansi Pemerintah Republik Indonesia, Lembaga Swasta Indonesia atau perseorangan Warga Negara Indonesia;

Dalam penjelasannya dijelaskan,

(1) Yang dimaksud dengan "perjanjian" adalah termasuk perjanjian Internasional yaitu setiap perjanjian di bidang hukum publik yang diatur oleh hukum Internasional, dan dibuat oleh Pemerintah dan negara, organisasi Internasional, atau subyek hukum Internasional lain. Perjanjian Internasional ditulis dalam Bahasa Indonesia, bahasa negara lain, dan/atau bahasa Inggris.

(2) Dalam perjanjian bilateral, naskah perjanjian ditulis dalam Bahasa Indonesia, bahasa nasional negara lain tersebut, dan/atau bahasa Inggris, dan semua naskah itu sama aslinya.

Berdasarkan penjelasan Pasal 31 tersebut, maka "kewajiban" ini berlaku pada perjanjian Internasional baik di bidang hukum publik maupun hukum perdata. Namun yang akan penyusun bahas adalah perjanjian Internasional dalam bidang hukum perdata saja atau biasa disebut perjanjian/kontrak bisnis Internasional karena dalam praktiknya, polemik hukum yang saat ini terjadi baik di kalangan akademisi maupun praktisi adalah mengenai permasalahan keabsahan kontrak bisnis yang menggunakan bahasa asing saja.

Pada bulan Juni 2013, syarat untuk menggunakan Bahasa Indonesia dikuatkan oleh putusan Pengadilan Negeri Jakarta Barat, yang

pengadilan perjanjian pinjaman antara PT Bangun Karya Pratama Lestari (selaku debitur Indonesia) dan Nine AM (selaku kreditur asing) dengan dalil bahwa versi Bahasa Indonesia dari kontrak (perjanjian) tidak ditandatangani. Berikut konstruksi pertimbangan hukum putusan, Pengadilan berpendapat bahwa :

....."Menimbang, bahwa oleh karena Loan Agreement yang ditandatangani oleh Penggugat dan Tergugat tertanggal 23-April-2010 (Vide Bukti P-10 dan T-20) yaitu sesudah UU No. 24 Tahun 2009 diundangkan maka tidak dibuatnya Perjanjian /Loan Agreement tersebut dalam Bahasa Indonesia adalah bertentangan dengan UndangUndang yang dalam hal ini adalah UU No. 24 Tahun 2009 sehingga merupakan perjanjian terlarang karena dibuat dengan sebab yang terlarang (Vide Pasal 1335 KUHPerdata jo. Pasal 1337 KUHPerdata). Sehingga tidak memenuhi salah satu syarat 
Esensialia dari syarat sahnya perjanjian sebagaimana yang ditentukan dalam ketentuan Pasal 1320 KUHPerdata, sehingga dengan demikian Perjanjian/Loan Agreement tertanggal 23-April-2010 yang ditandatangani oleh Penggugat dan Tergugat adalah batal demi hukum ;

Putusan Pengadilan Negeri Nomor 451/PDT.G/2012/Jkt.Brt ini telah dikuatkan pada tanggal 7 Mei 2014 oleh Pengadilan Tinggi melalui Putusan Pengadilan Tinggi No. 48/Pdt/2014/PT.DKI, bahkan putusan Pengadilan Negeri tersebut dikuatkan kembali di tingkat Kasasi.

Namun, ternyata sebelumnya, telah ada kasus serupa yakni sengketa antara Carpenter Asia Pacipic Pty Ltd melawan PT Tate Developments Land \& Consultancy. Dalam Putusan Pengadilan Negeri Praya Nomor : 35/PDT.G/2010/PN.PRA. tanggal 26 Januari 2011 yang lalu, dalam pertimbangan hakim menolak dalil penggugat yang mempermasalahkan penggunaan bahasa inggris dalam penyusunan kontrak tersebut. Adapun berikut cuplikan pertimbangan hakim Pengadilan Negeri Praya : " .Menimbang bahwa terhadap dalil gugatan Penggugat yang menyatakan perjanjian batal demi hukum karena dalam kontrak hanya dicantumkan 1 (satu) bahasa saja adalah terlalu berlebihan oleh karena dalam isi perjanjian tersebut telah disepakati oleh pihak Penggugat maupun Tergugat bahwa bahasa yang digunakan dalam perjanjian tersebut adalah hanya menggunakan 1 (satu) bahasa saja yaitu bahasa Inggris, sehingga dengan demikian terhadap dalil Penggugat tersebut haruslah ditolak."

Adanya dua putusan yang memiliki pertimbangan hukum berbeda di dalamnya menyoal penggunaan bahasa dalam kontrak menjadi sebuah polemik sendiri yakni ketidakpastian hukum. Di satu sisi, Pasal 31 UU Bendera, Bahasa dan Lambang Negara serta Lagi Kebangsaan mewajibkan penggunaan bahasa Indonesia dan hal ini menjadi pertimbangan hakim untuk memberikan putusan batal demi hukum atas kontrak yang hanya menggunakan bahasa asing. Namun, di lain pihak, perkara lain yang menyengketakan mengenai kontrak yang memiliki unsur asing pada Pengadilan Negeri Praya, UU Bendera, Bahasa dan Lambang Negara serta Lagu Kebangsaan tidak digunakan oleh majelis hakim dalam pertimbangannya terhadap gugatan penggugat yang menyoal penggunanan bahasa asing dalam kontrak. 
Berangkat dari persoalan perbedaan pertimbangan putusan hakim yang memiliki isu sama yakni penggunaan bahasa asing dalam penyusunan sebuah kontrak tersebut diatas serta pro dan kontra yang terjadi di kalangan akademisi maupun praktisi, maka peneliti tertarik untuk mengangkat judul Implikasi Hukum Terhadap Kontrak Bisnis Internasional Yang Dibuat Dalam Bahasa Asing.

\section{B. Metode Penelitian}

Metode penelitian yang dilakukan oleh penulis adalah metode kepustakaan sehingga jenis penelitian yang digunakan adalah yuridis normatif. Menurut Soerjono Soekanto, penelitian hukum normatif mencakup : penelitian terhadap asas-asas hukum, sistematika hukum, taraf sinkronisasi vertikal dan horizontal, perbandingan hukum, dan sejarah hukum.(Soekanto, 1995).Dalam penelitian ini, penyusun membatasi penelitian hukum normatif pada cakupan penelitian terhadap asas-asas hukum.

Data yang digunakan adalah data sekunder. Data sekunder dikumpulkan dengan cara membaca atau studi pustaka, mencatat, mengutip, membandingkan dan menghubungkan bahan-bahan hukum satu dengan yang lainnya sehingga menjadi satu kesatuan yang bulat dan utuh agar memudahkan pengelolaannya.

Data yang telah diolah tersebut kemudian dianalisis berdasarkan pada beberapa metode interpretasi (penafsiran) yaitu interpretasi gramatikal dan sistematis/logis.Dalam penelitian ini, penulis menggunakan beberapa jenis pendekatan yakni pendekatan perundang-undangan dan pendekatan kasus.

\section{Perumusan Masalah}

1) Bagaimana hubungan suatu kontrak bisnis internasional yang dibuat dalam bahasa asing dengan syarat sah perjanjian mengenai causa atau sebab yang halal?

2) Bagaimana implikasi hukum kontrak bisnis internasional yang dibuat dalam bahasa asing terkait adanya perbedaan pertimbangan dalam putusan hakim di dalam praktik?

\section{Kerangka Teori}

\section{a. Mandatory Rules}

Di dalam hukum kontrak/perjanjian maupun hukum internasional lebih dikenal dengan istilah "mandatory rules" yakni ketentuan hukum yang bersifat memaksa. Pengertian mandatory rules sama dengan pengertian hukum yang bersifat memaksa. Penjelasan singkat mengenai mandatory rules adalah sebagai berikut : 
"Mandatory rules are generally those rules that cannot be derogated from by agreement. The public law is full of ius cogens rules, in the private law more rules are dispositive but we can find there also ius cogens rules. Within the context of the topic mandatory rules are those ius cogens rules contained in the civil law acts (for example Commercial code, Civil Code etc.), that the parties of a contract must observe and cannot change by their agreement. If in the domestic contracts was contractually derogated the mandatory rule, this would be considered to be void." (Simona Travnickova Pravnicka, 2016)

Terjemahan bebas mengenai inti pernyataan diatas bahwa :

Secara umum Mandatory rules (ketentuan hukum yang bersifat memaksa) adalah ketentuan-ketentuan yang tidak boleh dikesampingkan dalam kesepakatan perjanjian. Dalam lingkup hukum publik pengaturannya secara keseluruhan adalah bersifat mandatory rules (memaksa) sebaliknya dalam hukum privat lebih cenderung pada ketentuan hukum yang bersifat mengatur tetapi kita juga bisa mendapati ketentuan-ketentuan tertentu yang bersifat memaksa. Para pihak dalam kontrak harus memperhatikan Mandatory rules dan tidak dapat mengenyampingkannya dalam pembuatan kontrak mereka. Akibat hukum jika kontrak mengenyampingkan mandatory rules, maka kontrak tersebut dapat dibatalkan/batal.

\section{b. Kepastian Hukum}

Teori Kepastian hukum mengandung 2 (dua) pengertian yaitu pertama adanya aturan yang bersifat umum membuat individu mengetahui perbuatan apa yang boleh atau tidak boleh dilakukan, dan kedua berupa keamanan hukum bagi individu dari kesewenangan pemerintah karena dengan adanya aturan hukum yang bersifat umum itu individu dapat mengetahui apa saja yang boleh dibabankan atau dilakukan oleh Negara terhadap individu. Kepastian hukum bukan hanya berupa pasal-pasal dalam undang-undang melainkan juga adanya konsistensi dalam putusan hakim antara putusan hakim yang satu dengan putusan hakim lainnya untuk kasus yang serupa yang telah di putuskan.(Marzuki, 2008)

\section{c. Yurisprudensi}

Yurisprudensi dapat berarti setiap putusan hakim.Yurisprudensi dapat pula berarti kumpulan putusan hakim yang disusun secara sistematis dari tingkat peradilan pertama sampai pada tingkat kasasi dan yang pada umumnya diberi annotatie oleh pakar di bidang peradilan.Selanjutnya yurisprudensi diartikan pandangan atau pendapat para ahli yang dianut oleh hakim dan dituangkan dalam putusannya. Di samping itu,di lingkungan peradilan dikenal apa yang disebut "yurisprudensi tetap". Apabila suatu kaidah atau ketentuan dalam suatu putusan kemudian diikuti secara 
konstan atau tetap oleh para hakim dalam putusannya dan dapat dianggap enjadi again dari keyakinan hukum umum, maka dikatakan bahwa terhadap masalah hukum tersebut telah terbentuk yurisprudensi tetap.(Sudikno Mertokusumo, 2014)

Dalam bahasa Perancis, Yurisprudence yang artinya keputusan hakim terdahulu yang diikuti oleh Hakim dan dijadikan dasar keputusan hakim lain mengenai kasus yang sama.(Sutami, 2011)

Tidak semua putusan hakim tingkat pertama atau tingkat banding dapat dikategorikan sebagai yurisprudensi, kecuali putusan tersebut sudah melalui proses eksaminasi dan notasi Mahkamah Agung dengan rekomendasi sebagai putusan yang telah memenuhi standar hukum yurisprudensi.

\section{Hasil dan Pembahasan}

1. Uraian Pertimbangan Pada Putusan Hakim Terhadap Dalil Gugatan Tentang Kewajiban Penggunaan Bahasa Indonesia Dalam Kontrak Bisnis Internasional

1) Pertimbangan Hakim Dalam Putusan Pengadilan Negeri PrayaNomor : 35/PDT.G/2010/PN.PRA. tanggal 26 Januari 2011

\section{a. Duduk Perkara}

- Carpenter Asia Pacipic Pty Ltd (berkedudukan di Australia, selanjutnya disebut PENGgUGAT) dan PT Tate Developments Land \& Consultancy (berkedudukan di Indonesia, selanjutnya disebut TERGUGAT.

- PENGGUGAT dan TERGUGAT kemudian menandatangani Contract Agreement tertanggal 8 Februari 2010 yang berisi tentang jual-beli Tanah yang dibuat dalam Bahasa Inggris saja.

\section{b. Dalil-Dalil Gugatan}

- ....." Bahwa ketentuan peraturan perundang-undangan mengatur bahwa Perjanjian harus dibuat dalam bahasa Indonesia juga meliputi atas setiap Perjanjian yang ditandatangani yang melibatkan pihak asing, diatur dalam Pasal 31 ayat 1 dan 2 Undang-Undang No. 24 Tahun 2009

tentang Bendera, Bahasa dan Lambang Negara serta Lagu Kebangsaan mewajibkan penggunaan Bahasa Indonesia.

\section{c. Petitum Penggugat Dalam Pokok Perkara :}

Primair :

1. Mengabulkan Gugatan PENGGUGAT untuk seluruhnya;

2. Menyatakan TERGUGAT telah melakukan perbuatan melawan hukum; 
3. Menyatakan tidak sah dan tidak berkekuatan hukum (batal demi hukum) atas Contract Agreement tertanggal 8 Februari 2010 yang ditandatangani oleh PENGGUGAT dan TERGUGAT;

\section{d. Pertimbangan Hakim}

- Menimbang bahwa terhadap dalil gugatan Penggugat yang menyatakan perjanjian batal demi hukum karena dalam kontrak hanya dicantumkan 1 (satu) bahasa saja adalah terlalu berlebihan oleh karena dalam isi perjanjian tersebut telah disepakati oleh pihak Penggugat maupun Tergugat bahwa bahasa yang digunakan dalam perjanjian tersebut adalah hanya menggunakan 1 (satu) bahasa saja yaitu bahasa Inggris, sehingga dengan demikian terhadap dalil Penggugat tersebut haruslah ditolak ; "

2) Pertimbangan Hakim dalam Putusan Nomor 451/PDT.G/2012/PN.Jkt.Bar
a. Duduk Perkara 
- PT Bangun Karya Pratama Lestari, perusahaan berbentuk Perseroan Terbatas yang didirikan berdasarkan hukum Negara Indonesia selaku Pengguggat mengajukan gugatan terhadap NINE AM Ltd, perusahaan kemitraan terbatas yang didirikan dan berdasarkan hukum yang berlaku di Negara bagian Texas, USA.

- Penggugat dan Tergugat mengadakan Perjanjian Pinjam Meminjam/ Loan Agreement tertanggal 23 April 2010

- Pilihan hukum dalam Loan Agreement tersebut disepakati untuk tunduk pada ketentuan-ketentuan hukum yang berlaku di Indonesia

- Loan Agreement tersebut hanya dibuat dalam bahasa Inggris................."

\section{b. Dalil-dalil gugatan}

- - LoanAgreementtidak memenuhi syarat formil karena hanya menggunakan bahasa inggris, sedangkan dalam Pasal 31 UU No. 24 Tahun 2009 tentang Bendera, Bahasa, Lambang Negara dan Lagu Kebangsaan mewajibkan penggunaan bahasa Indonesia dalam pembuatan perjanjian........"

\section{c. Petitum Gugatan}

\section{Dalam Provisi}

- Menyatakan untuk sementara waktu Tergugat dilarang melakukan penagihan kepada Penggugat

\section{Dalam Pokok Perkara}

- Mengabulkan seluruh gugatan penggugat

- Menyatakan Loan Agreement 23 April 2010 tersebut bata demi hukum atau setidak-tidaknya tidak memiliki kekuatan hukum mengikat

- Menyatakan Akta JAminan Fidusia atas benda tertanggal 27 April 2010 Nomor 33 yang merupakan perjanjian accesoir dari Loan Agreement batal demi hukum atau

setidak-tidaknya tidak memiliki kekuatan hukum mengikat.

\section{d. Pertimbangan Hakim}

- Menimbang bahwa memperhatikan surat bukti P-1A yang sama dengan surat bukti T2a yaitu Loan Agreement yang ditandatangani oleh Penggugat dan Tergugat tertanggal 23 April 2010 adalah dibuat dalam 1 (satu) bahasa yaitu Bahasa Inggris tanpa adanya Bahasa Indonesia, sedangkan ketentua Pasal 31 ayat 1 UU No. 24 Tahun 2009 tentang Bendera, Bahasa, Lambang Negara dan Lagu Kebangsaan yang diundangkan pada tanggal 9 Juli 2009 mewajibkan menggunakan bahasa Indonesia; 
- Sedangkan Peraturan Presiden sebagai Peraturan Pelaksana UU No 24 Tahun 2009 sebagaimana dimaksud dalam Pasal 40 UU No 24 Tahun 2009 yang dimaksud oleh Tergugat dalam jawabannya tidak dapat melumpuhkan katakata "Wajib" yang disebutkan dalam PAsal 31 ayat 1 UU No. 24 Tahun 2009 karena Peraturan Presiden mempunyai kedudukan yang lebih rendah dari Undang-Undang, demikian pula hanya dengan Surat Menteri HUkum dan HAM RI No. M.HH.UM.01.01.35 tanggal 28 Desember 2009 yang menjawab surat dari 11 (sebelas) Associate Pengacara perihal : Klarifikasi atas implikasi dan pelaksanaan UU No. 24 TAhun 2009 (vide Bukti P-10) yang paa intinya menyatakan bahwa penggunaan Bahasa Inggris pada perjanjian tidak melanggar syarat formil yang ditentukan dalam UU No. 24 Tahun 2009 sampai dikeluarkannya Peraturan Presiden sebagaimana ketentuan Pasal 40 UU No. 24 Tahun 2009 dan juga tidak dapat melumpuhkan kata-kata "Wajib" yang terdapat dalam

Ketentuan Pasal 31 ayat (1) UU No. 24 Tahun 2009 karena Surat Menteri tidak termasuk kepada tata urutan perundang-undangan ;

- Menimbang bahwa oleh karena Loan Agreement yang ditandatangani oleh Penggugat dan Tergugat tanggal 23 April 2010 (Vide Bukti P-10 dan T-20) yaitu sesudah UU No 24 Tahun 2009 diundangkan maka tidak dibuatnya perjanjian /Loan Agreement tersebut dalam Bahasa Indonesia adalah bertentangan dengan Undang-Undang sehingga merupakan perjanjian terlarang karena dibuat dengan sebab yang terlarang (Vide Pasal 1335 jo. 1337 KUHPerdata)

- Sehingga tidak memenuhi slah satu syarat Esensilia dan syarat sahnya suatu Perjanjian sebagaimana yang ditentukan dalam ketentuan PAsal 1320 KUHperdata sehingga dengan demikian Perjanjian/Loan Agreement tertanggal 23 April 2010 yang ditandatangani oleh penggugat dan tergugat adalah Batal Demi HUkum

- ........." Menimbang bahwa dengan demikian gugatan Penggugat haruslah dinyatakan dikabulkan untuk seluruhnya;

2. Analisis Yuridis Perbedaan Pertimbangan dalam Putusan oleh Hakim Terkait Dalil Gugatan Penggunaan Bahasa Dalam Kontrak Bisnis Internasional Pasca Berlakunya Undang-Undang Nomor 24 Tahun 2009 Tentang Bendera, Bahasa, dan Lambang Negara, serta Lagu Kebangsaan

1) Kewajiban Penggunaan Bahasa Indonesia Dalam Pembuatan Kontrak Pasca Undang-Undang No. 24 Tahun 2009 tentang Bendera, Bahasa, dan Lambang Negara, serta Lagu Kebangsaan

Sejak pengundangan Undang-Undang No. 24 Tahun 2009 tentang Bendera,

Bahasa, dan Lambang Negara, serta Lagu Kebangsaan pada tanggal 9 Juli 2009 ("UU

Bendera, Bahasa dan Lambang Negara serta Lagi Kebangsaan”), yang berdasarkan

Pasal 31 ayat (1) menyebutkan bahwa : 
"Bahasa Indonesia Wajib digunakan dalam nota kesepahaman atau perjanjian yang melibatkan Negara, Instansi Pemerintah Republik Indonesia, Lembaga Swasta Indonesia atau perseorangan Warga Negara Indonesia;

Dalam penjelasannya dijelaskan bahwa :

(1) Yang dimaksud dengan "perjanjian" adalah termasuk perjanjian Internasional yaitu setiap perjanjian di bidang hukum publik yang diatur oleh hukum Internasional, dan dibuat oleh Pemerintah dan negara, organisasi Internasional, atau subyek hukum Internasional lain. Perjanjian Internasional ditulis dalam Bahasa Indonesia, bahasa negara lain, dan/atau bahasa Inggris.

Dengan demikian "kewajiban" ini berlaku pada setiap perjanjian atau kontrak termasuk perjanjian Internasional.Pasal 31 ayat (1) baik yang dibuat antara para pihak yang berkedudukan hukum di Indonesia, pihak Indonesia dengan Asing, yang dibuat di

Indonesia dan tunduk pada hukum Indonesia. Pasal 31 tersebut telah mengubah cara untuk mendokumentasikan transaksi-transaksi yang terkait dengan Indonesia ataupun melibatkan pihak Indonesia karena penggunaan bahasa Indonesia dalam Undang-Undang ini bersinggungan dengan penyusunan kontrak (perjanjian) maka keterkaitan ini menimbulkan implikasi besar terhadap perkembangan dunia kontrak di Indonesia.

2) Analisis Tentang Pertimbangan Hakim dalam Putusan Nomor 35 PDT.G.2010/PN/PRA antara Carpenter Asia Pacipic Pty Ltd melawan PT Tate Developments Land \& Consultancy

Adapun berikut cuplikan pertimbangan hakim Pengadilan Negeri Praya :

"Menimbang bahwa terhadap dalil gugatan Penggugat yang menyatakan perjanjian batal demi hukum karena dalam kontrak hanya dicantumkan 1 (satu) bahasa saja adalah terlalu berlebihan oleh karena dalam isi perjanjian tersebut telah disepakati oleh pihak Penggugat maupun Tergugat bahwa bahasa yang digunakan dalam perjanjian tersebut adalah hanya menggunakan 1 (satu) bahasa saja yaitu bahasa Inggris, sehingga dengan demikian terhadap dalil Penggugat tersebut haruslah ditolak."

Berdasarkan konstruksi hukum dalam pertimbangan Majelis Hakim Pengadilan Negeri Praya tersebut dapat dilihat bahwa Majelis Hakim mengedepankan asas konsensual, kebebasan berkontrak dan pacta sunt servanda suatu kontrak.Hal ini menjadi sebuah catatan yang perlu dikaji serius oleh peneliti.

Di dalam hukum kontrak/perjanjian maupun hukum internasional dikenal dengan istilah "mandatory rules" yakni ketentuan hukum yang bersifat memaksa. 
Pengertian mandatory rules sama dengan pengertian hukum yang bersifat memaksa. Penjelasan singkat mengenai mandatory rules adalah sebagai berikut :

"Mandatory rules are generally those rules that cannot be derogated from by agreement. The public law is full of ius cogens rules, in the private law more rules are dispositive but we can find there also ius cogens rules. Within the context of the topic mandatory rules are those ius cogens rules contained in the civil law acts (for example Commercial code, Civil Code etc.), that the parties of a contract must observe and cannot change by their agreement. If in the domestic contracts was contractually derogated the mandatory rule, this would be considered to be void.(Simona Travnickova Pravnicka, 2016)

Terjemahan bebas mengenai inti pernyataan diatas bahwa :

Secara umum, Mandatory rules (ketentuan hukum yang bersifat memaksa) adalah ketentuan-ketentuan yang tidak boleh dikesampingkan dalam kesepakatan perjanjian. Dalam lingkup hukum publik pengaturannya secara keseluruhan adalah bersifat mandatory rules (memaksa) sebaliknya dalam hukum privat lebih cenderung pada ketentuan hukum yang bersifat mengatur tetapi kita juga bisa mendapati ketentuan-ketentuan tertentu yang bersifat memaksa. Para pihak dalam kontrak harus memperhatikan Mandatory rules dan tidak dapat mengenyampingkannya dalam pembuatan kontrak mereka. Akibat hukum jika kontrak mengenyampingkan mandatory rules, maka kontrak tersebut batal.

Berdasarkan uraian diatas dapat disimpulkan bahwa Hukum yang bersifat memaksa atau imperatif (dwingendrecht) atau Mandatory Rules, yaitu hukum yang dalam keadaan konkrit tidak dapat dikesampingkan oleh perjanjian yang dibuat oleh para pihak, yang berarti kaedah hukumnya bersifat mengikat dan memaksa, tidak memberi wewenang lain, selain apa yang telah ditentukan dalam undang-undang.

Terkait dengan transaksi bisnis internasional, Indonesia telah meratifikasi konvensi UNIDROIT yang didalamnya mengatur prinsip-prinsip mengenai transaksi-transaksi komersil internasional.Di dalam UNIDROIT. Dalam article 1.1 UNIDROIT menjelaskan bahwa :

\section{"1. Freedom of contract as a basic principle in the context of international trade}

The principle of freedom of contract is of paramount importance in the context of international trade. The right of business people to decide freely to whom they will offer their goods or services and by whom they wish to be supplied, as well as the possibility for them freely to agree on the terms of individual transactions, are the 
cornerstones of an open, market-oriented and competitive international economic order."

Di Pasal lain, UNIDROIT Principles juga mengatur mengenai mandatory rules terhadap kontrak bisnis yang dibuat para Pihak Article. 1.2

"3.Limitation of party autonomy by mandatory rules. With respect to the freedom to determine the content of the contract, in the first instance the Principles themselves contain provisions from which the parties may not derogate. See Art. 1.5. Moreover, there are both public and private law rules of mandatory character enacted by States (e.g. anti-trust, exchange control or price laws; laws imposing special liability regimes or prohibiting grossly unfair contract terms, etc.), which may prevail over the rules containedin the Principles. See Art. 1.4."

Pasal 31 ayat (1) UU No. 24 Tahun 2009, menyebutkan bahwa :

"Bahasa Indonesia Wajib digunakan dalam nota kesepahaman atau perjanjian yang melibatkan Negara, Instansi Pemerintah Republik Indonesia, Lembaga Swasta Indonesia atau perseorangan Warga Negara Indonesia;

Kontrak jual beli tanah antara Carpenter Asia Pacipic Pty Ltd dengan PT Tate Developments Land \& Consultancy, berdasarkan bunyi Pasal tersebut seharusnya harus dibuat dalam bahasa Indonesia, sebab melibatkan badan hukum yang berkedudukan dan tunduk pada hukum Indonesia, yakni PT Tate Developments Land \& Consultancy. Maka berdasarkan uraian di atas, dapat disimpulkan bahwa kebebasan berkontrak sifatnya adalah tidak mutlak sebab ada batas-batas yang memagarinya. Batas-batas tersebut antara lain adalah tidak boleh disimpanginya aturan-aturan hukum nasional. Batas ini dikenal dengan prinsip hukum latin yang berbunyi : "pacta private juri public derogare non possum. Oleh karena itu, seharusnya dalam pertimbangan hakim pada Putusan Nomor 35 PDT.G.2010/PN/PRA antara Carpenter Asia Pacipic Pty Ltd melawan PT Tate Developments Land \& Consultancy, menerima dalil gugatan yang diajukan oleh Penggugat yakni Carpenter Asia Pacipic Pty Ltd. Penolakan dalil gugatan Penggugat yang menggunakan UU No. 24 Tahun 2009 tidak tepat.

3) Analisis Tentang Pertimbangan Hakim dalam Putusan Nomor 451/PDT.G/2012/PN.Jkt.Bar antara PT Bangun Karya Pratama Lestari melawan NINE AM Ltd 
" Menimbang bahwa oleh karena UU No 24 tahun 2009 telah secara tegas mewajibkan Bahasa Indonesia digunakan dalam Nota Kesepakatan atau Perjanjian yang melibatkan Negara, Instansi Pemerintah Repubik Indonesia, Lembaga Swasta Indonesia atau perseorangan Warga Indonesia dan daya ikat suatu Undang-Undang adalah tanggal diundangkan yang dalam hal ini adalah sejak tanggal 9 Jui 2009 sehingga oleh karena itu setiap kesepakatan atau perjanjian yang melibatkan melibatkan Negara, Instansi Pemerintah Repubik Indonesia, Lembaga Swasta Indonesia atau perseorangan Warga Indonesia yang dibuat sesudah tanggal 9 Juli 2009 yang tidak menggunakan Bahasa Indonesia adalah bertentangan dengan UndangUndang yang dalam hal ini adalah UU No. 24 Tahun 2009 tersebut ; " ..”Menimbang bahwa oleh karena Loan Agreement yang ditandatangani oleh Penggugat dan Tergugat tanggal 23 April 2010 (Vide Bukti P-10 dan T20) yaitu sesudah UU No 24 Tahun 2009 diundangkan maka tidak dibuatnya perjanjian /Loan Agreement tersebut dalam Bahasa Indonesia adalah bertentangan dengan Undang-Undang sehingga merupakan perjanjian terlarang karena dibuat dengan sebab yang terlarang (Vide Pasal 1335 jo. 1337 KUHPerdata)

- Sehingga tidak memenuhi salah satu syarat Esensilia dan syarat sahnya suatu Perjanjian sebagaimana yang ditentukan dalam ketentuan PAsal 1320 KUHperdata sehingga dengan demikian Perjanjian/Loan Agreement tertanggal 23 April 2010 yang ditandatangani oleh penggugat dan tergugat adalah Batal Demi Hukum

\section{Melanggar Causa atau Sebab yang Halal}

Menurut majelis Hakim, dengan dilanggarnya UU No. 24 Tahun 2009, maka Loan Agreement yang dibuat tersebut telah tidak memenuhi syarat objektif keabsahan kontrak di Indonesia. Dalam Pasal 1320 KUHPerdata tersebut terdapat 4 (empat) syarat yang harus dipenuhi untuk sahnya suatu kontrak, yaitu :
a. sepakat mereka yang mengikatkan dirinya (de toesteming van degenen die zich verbinden);
b. kecakapan untuk membuat perikatan (de bekwaamheid om eene verbintenis aan te gaan);
c. suatu hal tertentu (een bepaald onderwerp); 
d. suatu sebab yang halal atau diperbolehkan (eene geoor-loofde oorzaak)(Hernoko, 2009)

Tidak terpenuhinya syarat subyektif berakibat suatu perjanjian dapat dibatalkan atau dapat dimintakan pembatalan oleh salah satu pihak, sedangkan tidak terpenuhinya syarat obyektif menyebabkan suatu perjanjian batal demi hukum secara serta merta atau perjanjian dianggap tidak pernah ada dan tujuan para pihak yang mengadakan perjanjian tersebut untuk melahirkan suatu perikatan hukum telah gagal. Dengan demikian, tidak ada dasar bagi para pihaknya untuk saling menuntut di depan hakim.

2. Relevansi Causa atau Sebab yang Halal Pada Pasal 1320 jo. 1337 KUHPerdata terhadap Dilanggarnya Pasal 31 UU No. 24 Tahun 2009

Undang-Undang tidak memberikan pegangan yang pasti tentang pengertian apa itu causa atau sebab dalam kontrak/perjanjian. Sebab dalam arti hukum ini tidak boleh dicapuradukkan dengan sebab dalam arti hukum alam. Dalam hal ini kita perlu mengetahui terlebih dahulu apa yang dimaksud dengan kata causa atau sebab.

Dalam HR (Hoge Raad) telah memberikan perumusan mengenai sebab yakni apa yang dimaksud para pihak dengan membuat perjanjian itu (HR 17-November 1922) atau apa tujuan atau maksud perjanjian itu.(Sophar Maru Hutagalung, 2013)

“sebab dari perjanjian ialah APA YANG DIMAKSUDKAN OLEH PARA PIHAK DENGAN MENGADAKAN PERJANJIAN ITU” (arres H.R. 17 Nopember 1922, Hoetink nomor 89) 
Atau juga : TUJUAN atau MAKSUD daripada perjanjian. Jika diartikan demikian, penegrtian sebab lantas tidak boleh dijumlahkan dengan maksud dari salah satu pihak (H.R. 3 Februari 1928, Hoetink nomor 91), meskipun seringkali adalah sukar untuk membedakan yang satu dari yang lain.”(Vollmar, 1984)

Dalam diskusi singkat penulis dengan Prof Garuda Wiko beliau menyampaikan bahwa terkait causa atau sebab ini, tidak hannya mengenai objek kontrak saja melainkan juga tujuan dari kontrak tersebut. Adapun pengaitan antara sebab yang halal dengan dilanggarnya Pasal 31 UU No. 24 Tahun 2009, Prof. Garuda Wiko,meyampaikan bahwa bukannya tidak ada relevansi penggunaan ketentuan sebab yang halal kita juga harus ingat bahwa hukum itu selalu berkembang”.

Selain itu, dalam bukunya, Prof. Busro menjelaskan bahwa pengertian sebab adalah tujuan daripada perjanjian, apa yang menjadi isi, kehendak dibuatnya suatu perjanjian.(Busro, 2012)

Berdasarkan uraian di atas, yakni Yurisprudensi Hoge Raad dan kenyataan bahwa memang di dalam Undang-undang belum didapati pengertian yang pasti mengenai kata "sebab" ini serta beberapa pendapat ahli di atas, penulis berpendapat bahwa pertimbangan Hakim terkait Loan Agreement yang dianggap melanggar "sebab yang halal" karena tidak dibuatnya

kontrak tersebut dalam Bahasa Indonesia sudah tepat dengan berlandaskan Pasal 31 UU No. 24 Tahun 2009 dan dengan mengaitkan syarat sah perjanjian yakni causa atau sebab yang halal. 
3. Implikasi Kontrak Bisnis Internasional Yang Dibuat Dalam Bahasa Asing Terkait Adanya Perbedaan Pertimbangan Dalam Putusan Hakim Di Dalam Praktik

Setiap putusan majelis hakim memiliki pertimbangan atau alasan hukum.Pertimbangan atau alasan hukum merupakan hal yang penting dalam konstruksi hukum pada putusan pengadilan. Adanya perbedaan pertimbangan terkait dalil gugatan terhadap kontrak yang hanya menggunakan bahasa asing tersebut di atas, maka dapat menimbulkan ketidakpastian hukum pada perkara yang sama pada masa yang akan datang.

Namun, perlu diingat bahwa sistem hukum di Indonesia adalah Civil Law yang tidak menerapkan asas preseden dalam yurisprudensinya tetapi asas bebas sehingga tidak menjadikan yurisprudensi sebagai keharusan untuk diikuti.Hakim bebas dalam membuat sebuah pertimbangan dan putusan.Secara hukum, kekuatan mengikat yurisprudensi bagi negaranegara Civil Law hanya mengikat secara persuasive precedent sehingga hakim-hakim dibawahnya atau setelahnya diperkenankan tidak mengikuti yurisprudensi.Penggunaan putusan hakim sebelumnya yang dipakai untuk memutuskan perkara di kemudian hari maka hal itu bukanlah karena putusan hakim sebelumnya mempunyai kekuatan hukum mengikat, melainkan karena hakim yang kemudian tersebut menganggap bahwa putusan hakim yang sebelumnya tersebut memang dianggap tepat dan layak untuk diteladani.

Berdasarkan pada uraian di atas, untuk Putusan Nomor 35 PDT.G.2010/PN/PRA belum bisamenjadi yurisprudensi karena tidak 
semua putusan pengadilan dapat menjadi yurisprudensi dan pertimbangan terkait penggunaan bahasa asing dalam kontrak dalam putusan tersebut belum layak untuk menjadi acuan bagi para hakim selanjutnya sebagai pedoman.Sedangkan, dikarenakan adanya kebebasan hakim dalam membuat sebuah putusan dan tidak ada keharusan hakim selanjutnya untuk mengikuti putusan hakim sebelumnya maka dalam hal ini dapat dikatakan bahwa Pengadilan Jakarta Barat tidak menjadikan putusan Pengadilan Lombok dengan pertimbangan hukumnya yang menolak dalil gugatan mengenai batalnya kontrak yang dibuat dalam bahasa asing saja sebagai pedoman atau acuan dalam membuat Putusan Nomor 451/PDT.G/2012/PN.Jkt.Bar antara PT Bangun Karya Pratama Lestari melawan NINE AM Ltd. Selain daripada itu, karena Putusan Nomor 451/PDT.G/2012/PN.Jkt.Bar antara PT Bangun Karya Pratama Lestari melawan NINE AM Ltd. telah sampai pada tahap kasasi di Mahkamah Agung dan Putusan Mahkamah Agung memperkuat putusan Pengadilan tersebut, maka pertimbangan dan putusan Nomor 451/PDT.G/2012/PN.Jkt.Bar tersebut layak untuk menjadi pedoman hakim selanjutya dalam membuat pertimbangan dalam putusannya pada perkara yang sama selanjutnya. Dengan demikian, implikasi hukum kontrak yang dibuat hanya dalam bahasa Asing saja adalah Batal Demi Hukum karena melanggar syarat sah perjanjian yakni sebab yang halal dan UU No. 24 Tahun 2009.

Selain daripada itu, terkait soal implikasi hukum kontrak bisnis internasional yang dibuat dalam bahasa asing tidak serta merta selesai 
begitu saja, meskipun sudah ada putusan Mahkamah Agung yang memperkuat akibat hukum kontrak yang dibuat dalam bahasa Asing saja adalah batal demi Hukum. Ketidakpastian Hukum dalam praktik pengadilan masih membayangi terkait tidak dibuatnya kontrak bisnis internasional dalam bahasa Indonesia, karena di Indonesia yang menganut sistem Civil Law tidak mengharuskan hakim selanjutnya untuk mengikuti yurisprudensi dalam memutus perkara yang sama.

\section{SIMPULAN}

Berdasarkan uraian yang telah dipaparkan dalam Bab-bab sebelumnya, maka didapat beberapa kesimpulan berdasarkan rumusan masalah dalam tulisan ini, yakni sebagai berikut :

1) Pertimbangan Putusan Pengadilan Nomor 451/PDT.G/2012/PN.Jkt.Bar antara PT Bangun Karya Pratama Lestari melawan NINE AM Ltd sudah tepat karena tunduk pada konsep mandatory rules dengan dasar hukum Pasal 31 ayat 1 jo. 1335 jo. 1337 KUHPerdata. Kata "wajib" yang terdapat dalam Pasal 31 ayat (1) UU No. 24 Tahun 2009 bahwa penggunaan bahasa Indonesia dalam kontrak merupakan suatu keharusan yang tidak boleh dilanggar dan jika dilanggar maka artinya bertentangan dengan Undang-Undang tersebut. Sedangkan pertimbangan hakim pada Putusan Nomor 35 PDT.G.2010/PN/PRA antara Carpenter Asia Pacipic Pty Ltd melawan PT Tate Developments Land \& Consultancy, yang menolak dalil gugatan Penggugat yakni Carpenter Asia Pacipic Pty Ltd. tidak tepat karena mengabaikan Pasal 31 UU No. 24 Tahun 2009 yang mengandung Mandatory rules.

2) Implikasi hukum kontrak bisnis Internasional terkait adanya perbedaan pertimbangan dalam putusan hakim ada adalah sebagai berikut :

1) Putusan Mahkamah Agung telah memperkuat Putusan Pengadilan Nomor 451/PDT.G/2012/PN.Jkt.Bar antara PT Bangun Karya Pratama Lestari melawan NINE AM Ltd sehingga akibat hukum kontrak yang dibuat dalam bahasa Asing saja adalah Batal demi Hukum. 
2) Ketidakpastian Hukum dalam praktik pengadilan masih membayangi terkait tidak dibuatnya kontrak bisnis internasional dalam bahasa Indonesia, karena perlu diingat bahwa bahwa sistem hukum di Indonesia adalah Civil Law yang tidak menerapkan asas preseden dalam yurisprudensinya tetapi asas bebas sehingga tidak menjadikan yurisprudensi sebagai keharusan untuk diikuti. Hakim bebas dalam membuat sebuah pertimbangan dan putusan.

\section{DAFTAR PUSTAKA}

Busro, A. (2012). Hukum Perikatan berdasar Buku III KUH Perdata. Yogyakarta: Pohon Cahaya.

Hernoko, A. Y. (2009). Hukum Perjanjian Asas Proporsionalitas dalam Kontrak Komersial. Surabaya: Karisma Putra Utaman.

Marzuki, P. M. (2008). Pengantar Ilmu Hukum. Jakarta: Kencana Pranada Media Group.

Simona Travnickova Pravnicka. (2016). Limitations Of Choice Of Law-Mandatory Rules And Internationally Mandatory Rules.

Soekanto, S. (1995). Penelitian Hukum Normatif Suatu Tinjauan Singkat (4th ed.). Jakarta: Raja Grafindo Persada.

Sophar Maru Hutagalung. (2013). Kontrak Bisnis Di ASEAN, Pengaruh Sistem Hukum Common Law dan Civil Law. Jakarta: Sinar Grafika.

Sudikno Mertokusumo. (2014). Penemuan Hukum Sebuah Pengantar. Yogyakarta: Cahaya Atma Pustaka.

Sutami, S. (2011). Pengantar Tata Hukum Indonesia. Bandung: Refika Aditama.

Vollmar. (1984). Pengantar Studi Hukum Perdata Jilid II. Jakarta: Raja Grafindo Persada. 